\title{
The Illusion of Untranslatability: A Theoretical Perspective with Reference to the Translation of Culture-Bound Euphemistic Expressions in the Qur'an
}

\author{
A.Ali H. Al-Saidi (Corresponding author) \\ Faculty of Modern Languages and Communication, University Putra Malaysia, Malaysia \\ E-mail: brunosaidi8@gmail.com \\ Sabariah Md Rashid \\ Department of English, Faculty of Modern Languages and Communication, University Putra Malaysia, Malaysia \\ E-mail: smrashid@upm.edu.my
}

\author{
Received: 25-11-2015 \\ Accepted: 04-02-2016 \\ Advance Access Published: March 2016 \\ Published: 01-05-2016 \\ doi:10.7575/aiac.ijalel.v.5n.3p.81 \\ URL: http://dx.doi.org/10.7575/aiac.ijalel.v.5n.3p.81
}

\begin{abstract}
The present study investigates the notion of untranslatability where the concept of equivalence is reconsidered since the misconceptions, related to the said concept, inevitably lead to the emergence of untranslatability. Identifying equivalence as relative, approximate and necessary identity makes the notion of untranslatability a mere theorization. The objectives of the present study are (1) to investigate the notion of untranslatability in terms of the misconceptions associated with the concept of equivalence (2) to examine the possibility of translatability from Arabic into English focusing on culture-bound euphemistic expressions in the Quran as an area of challenge in translation. Data on the translation of culture-bound euphemistic expressions were purposively selected from the Quran and its four identified English translations. Ten examples were randomly selected and the criterion for their selection is that they are culturebound and therefore translation-resistant. Qualitative content analysis was used to examine the source data by referring to traditional exegetical books to determine the source text intentionality. Additionally, the translated data were analyzed according to the functional equivalence proposed by Nida $(1993 ; 2001)$.Findings of this study revealed that translatability is always possible and, accordingly, untranslatability is no more valid.
\end{abstract}

Keywords: Equivalence, Functional equivalence, untranslatability

\section{Introduction}

In order to better understand what it means to refer to certain aspects of language as 'untranslatable', two key important concepts have to be taken into account, namely, translation equivalence and culture. Inevitably, the notion of untranslatability (NOU) can never be examined in isolation of the two mentioned concepts which, undoubtedly, matter significantly to the emergence of this notion in translation studies. Until the 1960s and 1970s, the major focus of translation studies had never gone beyond the linguistic barriers (Wilss, 1992; House, 2009). Unfortunately, cultural elements had entirely been neglected to the extent that even the early works of the prominent scholars in translation, like Nida,1964,1969; Newmark,1981,1988, among others, included no reference to 'culture' as a fundamentally determinant factor in translation (Bassnett, 2002; Badawi,2008).

Additionally, recent deeper studies have made a turning point in translation by stating that translation is not merely purely linguistic-based, but meaning, as the core of any translation, is associated not only with language and text (House, 2009). Meaning is more bound to "the author and the reader who form the triad in understanding the appropriate meaning of any text" (Samuel and Samuel, 2007, p.375). In line with this, it has been widely-acknowledged that languages are 'inseparable' from their cultures and they, especially those belong to the dramatically different cultures, encode the world differently via establishing a highly diversified culture-specific ways which accordingly discredit the claim of finding the illusionary one-to-one correspondence or total equivalence (Cymbalista, 2003, p. 23). Consequently, the NOU is critically examined to figure out if it really does exist or it is a merely theorized on ungrounded and illusive arguments resulting from unawareness, of the early and even many of the latter scholars in translation, of the entire connectedness of language and culture and the dynamism they both have (Bassnett, 2002, House, 2009).

Despite the fact that there are still some language points that are deemed difficult to translate, however, the principle of translatability has increasingly gotten universal acknowledgment as the general rule in translation theory and practice (Cui, 2012). In other words, the NOU should not be taken as "a rule stating that it is impossible to create a text in the target language in the form of a text previously written in the TL. Untranslatability concerns some special cases that can be interpreted as the exceptions to the general rule of translating from one language to another" (Cluz, 2001, p.23). 
Most importantly, translators' awareness of fact that structural differences languages have are no obstacles to translation since each "linguistic community has the potential of expressions which generates resources for verbalizing every extralinguistic nuance including those which go beyond its own social and cultural experience" (Sculte and Biguenet, 1992 cited in Samuel and Samuel, 2007, p.375). Additionally, meaning is still be adequately transferred from one language to another cross-culturally, according to which the cultural gap has increasingly been bridged as a result of globalization and communication technology that gets even different cultures to become more closely accessible (Bahameed, 2008; Badawi, 2008). More to the point, it is stated that "in the course of the past one and a half millenniums some of the terms once considered untranslatable and used to pose an insurmountable problem for both translators and scholars, are nowadays well-established words in the lexicon of many languages and can easily be translated" (Abu-Mahfouz, 2011, p.66).

With these issues in mind, the problem to be examined in this study is that the COE has long been ill-defined and not well-conceptualized. Furthermore, the meaning of equivalence, which first originated in German to signal exact science, has entered English specialized literature on translation (Snell-Horny, 1988, p.14). Accordingly, this study attempts to answer the following research questions:

1. What causes the NOU to emerge in translation theory and practice?

2. To what extent does the reconsideration of the COE help make the NOU open to dismissal?

\section{Related Literature}

\subsection{Catford's Notion of Untranslatability}

The NOU was first raised by Catford in 1965 where he distinguishes between the linguistic and cultural untranslatability arguing that that the former is more associated with the difference between the source language (SL) and the target language (TL) in terms of formal features peculiar to them, whereas the latter is the resultant consequence of the absence in the TL of relevant situational features (Catford, 1965, p. 94-101). More specifically, Catford states that "in linguistic untranslatability the functionally relevant features include some which are in fact formal features of the SL text. If the TL has no formally corresponding feature, the text, or the item, is (relatively) untranslatable" (p.94). It is further a kind of failure "to find a TL equivalent is due entirely to differences between the source language and the target language" (Catford, 1965, p.98). The examples that include linguistic untranslatability, as Catford provided, are ambiguity, plays on words, ...etc.(p.96-98). As for cultural untranslatability, he adds that "what appears to be a quite different problem arises, however, when a situational feature, functionally relevant for the SL text, is completely absent in the culture of which the TL is a part" (p. 99). Admitting that cultural untranslatability is less 'absolute' than the linguistic untranslatability, Catford comments that

To talk of 'cultural untranslatability' may be just another way of talking about collocation untranslatability: the impossibility of finding an equivalent collocation in the TL". And this would be a type of linguistic untranslatability (p.101).

In the light of the above arguments, it seems that Catford first described what he termed 'cultural untranslatability' as less absolute than the linguistic one but he came to no avail when he strived to distinguish between them and the difference between them, according to his own words, was still hazy. He finally concluded that "the validity of the differentiation between linguistic and cultural untranslatability is questionable" (De Pedro, 1999, p.551).

However, Snell-Hornby (1988, p.19-20) has severely criticized Catford's definition of equivalence in particular and his approach to translation in general describing them respectively as 'circular' and 'hopelessly inadequate'. Her arguments in this regard are based upon the fact that translation process cannot simply be interpreted in terms of linguistic theory alone as what Catford has claimed since some other factors, i.e. textual, cultural and situational should be carefully considered when translating (Snell-Hornby,1988). Besides, Catford's notion of untranslatability has been described as a 'myth' and therefore 'divorced from reality' since it yields the paradox to translation in practice (John, 2011).

The main pitfall in Catford's approach is its focus on 'full equivalence' that is quite concerned with the 'context-free semantic sense' while this approach sadly neglects the functional equivalence that relies heavily on the 'contextsensitive communicative' value of that text (Bell, 1991) and for which an equivalence of some kind is always possible (Newmark, 1988). Moreover, Bassnett (2002) criticizes Catford by identifying that he "starts from different premises, and because he does not go far enough in considering the dynamic nature of language and culture, he invalidates his own category of cultural untranslatability" (p.40).

\subsection{The Concept of Equivalence: A New perspective}

As for as the COE is concerned, Snell-Hornby $(1986 ; 1988)$ has objected, discredited and even rejected the notion of equivalence describing it as an illusion (Wills, 1992; House, 1997; Belanos, 2002). It is of importance to stress that Snell-Hornby's claims are based upon two main arguments. Firstly, she reacts against the notion of equivalence because she was badly influenced by the narrow view the linguistic approach to translation provided to equivalence for until" the [1970s] the science of translation considered the concept of equivalence partially in a rigid and static way" (Wilss, 1992, p.197). Further, Wills points out that Snell-Hornbys' attempt to dismiss the notion of equivalence is quite questionable because "the modern science of translation, as repeatedly pointed out, presents arguments by referring to texts and one cannot actually relate ST and TT but through a form of some micro- or macro-textual equivalent 
relation"(p.197).Secondly and most importantly, Snell-Hornby believes that the meaning of equivalence, which first originated in German to signal exact science, has entered English specialized literature on translation with the meaning of qualitative sameness (Snell-Horny, 1988, p.14). She adds that

Áquivalenz -as a scientifically fixed constant for a given goal [in German]- is too static and onedimensional, and on the other hand equivalence has been watered down up to the loss of its meaning. Equivalence itself is not equivalent, although the similarity fakes: the borrowing from the exact sciences has turned out to be an illusion (p.15).

To discuss Snell-Hornby's arguments systematically, it is better to provide a summary of House's (1997) comments in this regard. House confirms that 'equivalence' has clearly nothing to do with the 'absolute identity' and the attack directed against the COE by Snell-Hornby (1986, p.12 ff) is unjustifiable (House, 1997, p.26), because in her analysis of the of the English and German dictionary, Snell-Hornby has presented meanings of the term 'equivalence' that supports her claim while ignoring some other meanings of the term that do not serve her purpose (House, 1997). More specifically, Snell-Hornby singles out one particular dictionary entry according to which "equivalence basically equals identity and that it means 'virtually the same thing'"(House, 1997). By contrast, the dictionary entries that House searched, regarding both terms 'equivalent' and 'equivalence', show that they clearly mean 'having the same value, purpose ... etc. as a person or thing of a different kind (Longman Dictionary of Contemporary English 1995), and 'having the same relative position or function' (Shorter Oxford English Dictionary 1993), as well as ' something that has the same use or function as something else' (Collins 1987). Furthermore, even in German, the term 'Áquivalenz' does not only mean the exact identity 'exakte Wissenschaften', as Snell-Homby claims, but also express some other meanings nearly similar to the meanings outlined in the above English dictionaries (House, 1997; see also Belanos, 2002).

Based on the above discussion, it is evident that Snell-Hornby's claims are not grounded on an exhaustive overview of the nature and the use of the COE in translation theory and these claims are, therefore, incomprehensive and unconvincing. Furthermore, Belanos (2002) posits that the 'total identity' meaning the COE has "traditionally been given in the so-called exact sciences does not entail that this very same meaning should be maintained when using the notion of equivalence in translation theory..., and to think of equivalence in this sense would be linguistically rather a naive idea" (p.72). Besides, Yinhua (2011) points out that equivalence should not be perceived in terms of exact or same identity, but rather as kind of similar or approximate relation between the ST and the TT because there are no two words that have exactly the same meaning even within one language (p.169).

Accordingly, the notion of untranslatability is open to dismissal since most of the prominent theorists and scholars of the modern translation theory have stressed that 'nothing is untranslatable' (Nida, 1975; Newmark, 1988; Belanos, 2001; House, 2009; Yinhua, 2011; Porzucki, 2014). For instance, (Nida, 1975 cited in Faisal, 2014, p.339) states that "anything that is said in one language can be said in another with reasonable accuracy", and that the translator is not, at all, excused to afford the saying that something is untranslatable (Newmark,1988, p.6). Furthermore, it is stated that "all languages have the resources to express any experience in an equivalent manner" (House, 2009, p.40). Moreover, untranslatable, as Wood (cited in Porzucki, 2014) asserts, "doesn't mean you can't make someone understand a word in another language at all. It's rather that nagging feeling that you're missing something interesting when you try to explain its meaning" (p.2).

In a nutshell, Catford's notions of linguistic and cultural untranslatability seem to collapse since as De Pedro (1999) asserts that Catford's premises in this regard are contradicted by practical evidence that even the "phonological devices of the source text (such as rhyme, for example), can be compensated in the target text by means of syntactical elements (some form of iteration), thus "translating" the rhythm of the text " (p. 551). Further, Benjamin (1992 cited in De Pedro, 1999, p.549) emphasizes the kinship of languages as stating that "languages are not strangers to one another, but are, a priori and apart from all historical relationships, interrelated in what they want to express...It is the task of the translator $[\ldots]$ to liberate the language imprisoned in a work in his re-creation of that work." (p.73, 80). In this light, claiming that culture is deemed untranslatable runs the risk that translation itself will never exist, which contradicts reality since this had never happened throughout human history and untranslatability is, therefore, just a false theorization (Faisal, 2014, p. 341).

\subsection{Exegetically-based Functional Equivalence}

Functional Equivalence (FE), often called dynamic or meaning-based translation or even inaccurately termed paraphrasing, is roughly defined as a translation strategy by virtue of which the translator's main concern is to render the ST content rather than its form (Motamadi, 2008). In more detail, FE refers to producing in the target culture a TT whose function is, as approximately as possible, similar to that of the ST by providing culture-neutral words (Newmark, 1988, p.83). He also asserts that "this procedure occupies the middle, sometimes universal, area between the SL or culture and the TL or culture. This procedure is the most accurate way of translating "(p. 83). As for Nida (1982), who originally used the term, FE is mainly concerned with highlighting the impact the SL message has on the TL readers. The following often-quoted diagram may best illustrate Nida's theory of FE. 


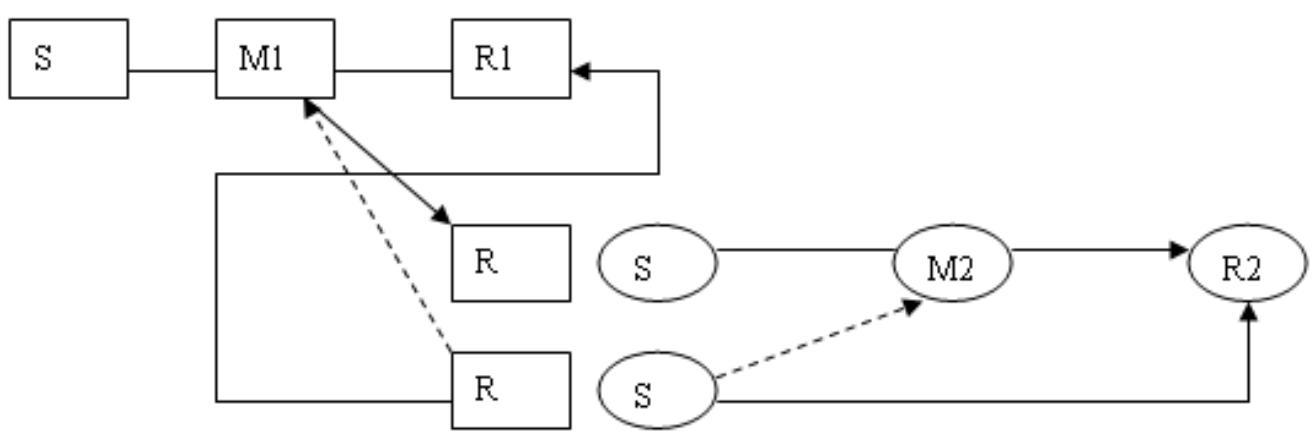

Figure 1. (Nida, 1982, p.22)

The first box stands the ST speaker who sends the first message (M1) where (R1) refers to the original receptor of that message. The translator is the second receptor $(\mathrm{R})$ of the same text, but in a totally different socio-cultural context, with a new message (M2). This last message is what the translator aims to make understandable to last receptor (R2) where the difference between the source and the target languages and their different cultural settings are clearly shown by using different shapes in the diagram above (Shiflett, n.d., p.30)

According to Nida (1993), FE is the best strategy in translating culture according to three important principles as stated below (p.30). Firstly, FE is mostly appropriate if formal translation leads to misunderstanding of the original designative meaning; secondly, FE is used if formal translation makes no sense and; thirdly and most importantly, FE is resorted to when a close, formal translation is likely to distort the associative meanings of the original in terms of stylistic value. In all the above cases, proper adjustments are required to reflect the ST associative values in the TT (p.125). Furthermore, Nida (2001) asserts that FE is best viewed in terms of 'the range of adequacy' in translation since this kind of equivalence indicates that complete or total equivalence does not exist, but different translations show varying degrees of equivalence.

In addition, Vehmas-Lehto (1999: 70-71 cited in Ranua, 2009, p.13-14) states that when adopting FE, a translator mainly focuses on the function or functions of both the ST and the TT, as the same or at least very close to each other, taking into account that the function of a given text generally refers to the purpose behind producing such a text. Admittedly, the function of a text can be determined not only as being the purpose for which the text is used but it is rather the ability of that text to create a specific communicative effect on the TT receptor. FE, according to Motamadi (2008), represents a newer theory of translation where the translator, according to which, attempts "to make the TT function the same way the ST functioned for the original readers" (p. 95).

The merits of FE are undeniably widely-acknowledged by many translation theorists and scholars such as Nida (1993, 2001), Newmark (1988), Harvey (2002), Ranua (2009) and Zhang (2010), among others. Weston (1991), for instance, asserts that FE, as a translation technique, can be regarded as the ideal method of translation (p.23). More importantly, Zhang (2010), based on Nida $(1993,2001)$ rightly posits that FE can be adequately understood if we take into account three main aspects, namely, the notion of equivalence, the notion of the receptors response and the notion of diversity ( Zhang, 2010, p.881). More specifically, FE is described by Nida (1964) as "the closest natural equivalent to the sourcelanguage message" (p.166) where three essential terms are used, i.e. closest, natural and equivalent. It is necessary to identify that "equivalence", in Nida's definition does not refer to the meaning of "total identity" but rather "proximity" and 'similarity' that are implied in the use of 'closest'. The term "natural", on the other hand, requires that the translation should be readable and understandable to the target audience (Zhang, 2010, p.881).) He also asserts that

the ideal situation is to make the version "closest" to the original message both in form and meaning. No aspect should be especially emphasized at the expense of the other, but, actually, in the practice of translation, the problem between language form and utterance meaning will always occur, especially when culturally-loaded words or expressions are involved (p.882).

In short, since this study examines a highly sensitive text such as the Qur'an, applying PE depends upon the extent to which the ST permits because it is not welcomed to provide, through applying PE, undesirable associations or deviations from the ST linguistic and/or cultural norms. Therefore, FE is guided by making reference to the more reliable exegetical books that determine the ST intentionality and function(s).

\section{Methodology}

\subsection{Research Approach}

This study is qualitative in nature since it is basically concerned with text analysis. The data comprised a total of 60 Arabic CBEEs and their translated counterparts in English by non-Muslim translators, namely, Sale (1734), Rodwell (1861), Arberry (1955) and Cleary (2004). However, this paper analyses only10 such examples, which fall under the categories of sexual intercourse, sexual intention and bodily parts. 
The data examined were selected according to four criteria:1) the ST data, termed CBEEs, constitute an area of challenge in translation,(2) the TT data are the Qur'an translations from Arabic, (3) The translators examined, who are native speakers of English, are assumed to have insufficient cultural and pragmatic knowledge of the ST, and (4) On the contrary, the translators selected are judged to have the essential socio-cultural knowledge to providing the functional translation equivalence.

\subsection{Data collection procedure}

In this study, collecting the data required the researcher to read the Qur'an in its original language as the first step to sort out the examples that have CBEEs. Second, the sorted-out examples were classified into three main topics that constitute the interest of this study, namely sexual intercourse, sexual intention and genitals. Then, the target versions of these issues are spotted out from the selected translations. In short, data collection includes three steps: the first involved identifying the examples of the CBEEs in the Qur'an; secondly, classifying them into the main issues related to the given Qur'anic topics, and finally, outlining the English translations of the CBEs in the Qur'an.

\subsection{Data Analysis}

The data are analyzed according to the following steps:

First, to determine ST intentionality and function, two major tafsiirs, namely Ar-Razi (1981) and Qutb (2003), among others, are referred to in this study so as to avoid any biased interpretation. These widely acknowledged exegetical books view the Qur'an from a linguistic and rhetorical perspective. Second, the TT examples were examined through comparing and contrasting the meaning they convey with the ST intended meanings determined. Third, the strategies adopted, by the translators selected, were critically analyzed in terms of whether they provide the functional equivalence to the ST examples or not. Fourth, the TTs were further analyzed according to exegetically-based functional equivalence (EBFE) theorized on Nida $(1993 ; 2001)$ to assess renderings of the ST meanings intended. Fifth, the STs and the TTs were analyzed contrastively via comparing them with each other and with the Qur'an to identify the points of similarities and differences. This methodology is adopted for it is more applicable to the analysis of the translations of CBEEs in the data examined. In other words, the model employed provides the translator with more freedom to opt for the more communicative rendering when it comes to deal with the unconventionally implied meanings, like those expressed by CBEEs in the Qur'an. Finally, the English equivalents used in the TT were also examined in terms whether they have approximate or similar euphemistic meaning and function of the ST or not. This task was achieved via consulting two widely reliable English dictionaries of euphemism, namely 'A dictionary of Euphemisms \& Other Double-talks by Rawson (1981), and How Not To Say What You Mean: A Dictionary of Euphemism by Holder, R.W.(2008) where the etymology, meaning and function of every euphemistic expression used in the translations investigated, was identified fully in comparison with the original. Furthermore, this study recommended an alternative translation for the translations that provide no pragmatic and/or functional equivalence to the SL euphemistic expression. The proposed translations are taken from the literature available on the Quran translations the researcher has within his reference (Hilali and Khan, 1977; Dawood, 1978; Hulusi, 2013; among others) .

\section{Results and discussions}

In this part, four published English translations of the CBEEs by non-Muslims were assessed through comparative analysis with the ST (the Qur'an). The analysis aims at finding to what extent each translator has captured the ST intention and function. The following discussion falls into three main categories of the CBEEs, namely, sexual intercourse, sexual intention and private parts.

\subsection{Sexual Intercourse}

Example (1)

\begin{tabular}{|c|c|c|}
\hline Source text & \multicolumn{2}{|c|}{ Target text } \\
\hline 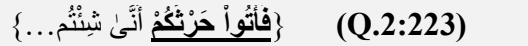 & " go unto your tillage " & (Sale) \\
\hline Translit. fa/too harthakum anna shi/tum & "go in to your field " & (Rodwell) \\
\hline Lit. go to your field as you will.. & "so come unto your tillage" & (Arberry) \\
\hline
\end{tabular}

In example (1), the euphemistic expression 'fa'too" (lit. come to), refers to sexual act and it implies an imperative to Muslims to have intimate relationship with their wives (al-Qurtubi, 2006, vol.2, p.90; Al-Omoosh, 2010, p.61). In line with this, the context of this verse is associated with a debatable viewpoint, among Muslims, regarding whether copulating with wives from the front and back position permitted or not. Accordingly, this verse regulated Muslims that they could contact their women sexually the way the like providing that the penetration is vaginal (Ar-Razi, 1981, vol.6, p.75; Qutb, 2003, p. 242).

In said example, 'fa'too' is translated into 'go unto' and 'go in to' by Sale and Rodwell respectively and they seem to be unaware of the meanings the euphemistic use of 'go' when followed by certain prepositions.' Go to ', for instance, express sexual act with a strong lustful desire and it is much more vulgar term, and ' go to' also implies negative connotations since it is more concerned with "copulation with, of either sex, or of homosexuality..." (Rawson, 1981, p.123; Holder, 2008, p.199). Consequently, this translation is quite inappropriate to the relevant Qur'anic context because it reflects the translators' lack of the socio-pragmatic contextual knowledge of the ST. In comparison, 'fa'too' is 
rendered into 'come un/to' by Arberry and Cleary where this euphemistic expression functionally expresses both the intended meaning, i.e., sexual intercourse and the function, legality of the said act, since 'come to' implies imperative to "copulate with [your wives] particularly in a marriage"(Holder, 2008, p.129; see Rawson, 1981, p.53).

Example (2)

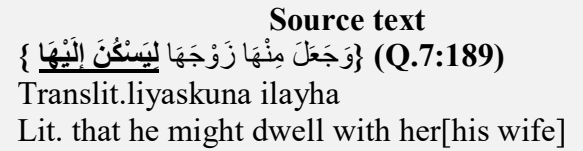

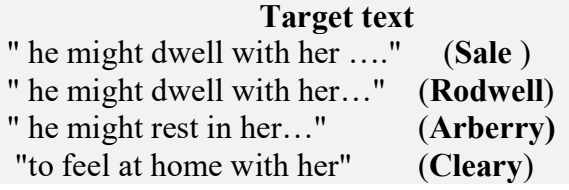

In the above verse, the word 'sakkan' (lit. to live with ) in expressions like 'liyaskuna ilayha' in the verse above is a euphemism that expresses the utmost kind of love and intimacy through sexual relation between spouses since they are described as one soul (Al-Tabari, 2000, Qutb,2003). The verse in example (2) was contextually revealed to remind humans of God's signs among which are that He created them from a single soul, namely, Adam, and made his spouse, Eve, out of him. The purpose behind this creation is that Adam might live in ultimate peace with his wife through being intimate with her and to bring offspring as a result. (http://www.altafsir.com).

The euphemistic expression 'liyaskuna ilayha', is translated into 'dwell with her' by Sale and Rodwell, and such a literal translation is more general and convey non-sexual connotation because the verb 'dwell' has never been used to express any sex-related meaning (Rawson, 1981, Holder, 2008). Further, 'dwell' does not even convey the general meaning of the said expression' 'liyaskuna ilayha' in the ST which entails the ultimate level of living in peace and satisfaction with a wife (Qutb, 2003, p.3763). In contrast, the ST is transferred into 'he might rest in her' by Arberry and this expression is also more general and, as euphemism, is more associated with "the relaxation that is obtained through death, as in eternal rest, called to heavenly rest, go to rest, and laid to rest " (Rawson, 1981, p.236). As for Cleary, the ST is rendered into a more literally general expression, i.e. 'to feel at home with her', which is irrelevant to sex (Rawson, 1981, p.136-7) and indicates the translator's unawareness of the ST intention. The following translation may be more illustrative:

-"He might find comfort in her" ( Dawood, 1978, p.262).

The use of 'comfort in her' as equivalence to 'liyaskuna ilayha' is a real success since 'comfort' is a euphemistic expression for intimate copulation especially when sought by a male (Holder, 2008, p.129).

Example (3)

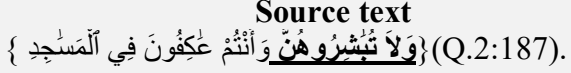

Translit. wala tubashiroohunna

Lit. Do not contact them [your wives].

\begin{tabular}{lc}
\multicolumn{2}{c}{ Target Text } \\
"Go not in unto them" & (Sale) \\
"go not unto them" & (Rodwell) \\
"Do not lie with them" & (Arberry) \\
"Do not make love with" & (Cleary)
\end{tabular}

In the example above, the euphemistic expression 'bashiroohunna'(lit. contact them), used twice, is derived originally from the word bashrah (human skin) since the meaning intended implies the married couples' skin-to-skin contact, i.e. sexual act. It is worth noting that 'bashiroohunna' indicates a high degree of intimacy and romance (Ar-Razi, 1981, vol.5, p.216; Az-Zamakhshari, 1998, vol.2., 114).

Accordingly, the word 'bashiroohunna' is translated into 'go in unto them' by both Sale and Rodwell. This English euphemistic expression denotes negative connotations due to its relevance to meanings such as lustful sexual desire and homosexuality which are unsuitable to the Qur'anic context (see Holder, 2008, p.198-199). In comparison, the said expression is rendered into 'lie with them' by Arberry and the English euphemistic expression involves sexual intercourse (Holder, 2008, p.247). However, the said expression has negative connotation because it implies extramarital copulation and it is thus more squeamish (Rawson, 1981, p.169; Holder, 2008, p.247). More to the point, Cleary's use of 'do not make love with' as an equivalence to the ST entails a lot of negative meanings for this euphemistic expression is mainly used for "homosexual activity [and] to make love with yourself is to masturbate"(Holder, 2008, p.256). Thus, this translation is quite unfitting to the Qur'anic context which indicates the utmost level of love and intimacy between married couples while having sexual relation. The translation that may best convey the ST to use 'contact with' which is a well-established euphemism that expresses 'sexual activity' that is heterosexual and implies mutuality between the married couples (Holder, 2008, p.134). Furthermore, this euphemistic expression involves the physical contact as part of the sexual operation and this is quite similar to the intended meaning in the ST since the meaning 'bashiroohunna' comes originally from skin-to-skin contact as stated so far (see Ar-Razi, 1981 and Az-Zamakhshari, 1998, among others).

Example (4)

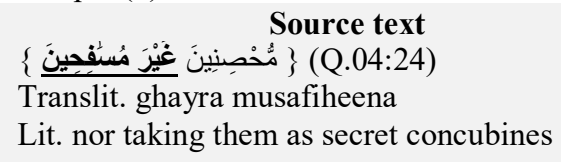

Target text

"Avoiding whoredom"

" without fornication"

and not in license

not prostituting them

(Sale)
(Rodwell)
(Arberry).
(Cleary)

The euphemistic term musäfihina is used euphemistically to make indirect reference to the Arabic word' zina'(adultery) and musäfị̄ina is linguistically derived from the verb safaha which literally means 'pouring water without barrier'. 
Accordingly, musäfaha or sifah are euphemisms for adultery since it involves no marriage contract (Az-Zamakhshari, 1998, vol.5, p.231; Al-Qurtubi, 2006, vol.5, p.127; Al-Omoosh, 2010, p.76; Abdul Fattah, 2014, p.20).

In terms of translation, musäfihina is rendered into 'whoredom' and 'fornication' by Sale and Rodwell respectively and they attempt to communicate the intended meaning but via turning the ST euphemistic expression into a bluntly dysphemistic TT. They consequently threaten the target reader's face since making direct reference to 'whoredom' and 'fornication' is quite embarrassing to the target reader. This is, in fact, a total socio-pragmatic failure since the appropriateness in euphemizing the ST is not only lost in the TT but is also replaced by a dysphemistic expression. Similarly, musäfihina is translated into' prostituting them' by Cleary where the ST that is highly euphemized is changed into a face-threatening dysphemistic expression. In a nutshell, none of the three translators cited have captured the ST message and they therefore run the risk of embarrassing their target reader, i.e. show a socio-pragmatic failure. In contrast, the ST is rendered into 'in license' by Arberry which seems less negative than the expressions used by other translators for it is euphemistic expression though not well-established and never listed in the dictionaries of euphemism consulted in this study (see Rawson, 1981 and Holder, 2008). The ST may be better translated into 'sinful commerce' which refers to extramarital sexual relationship (Holder, 2008, p.346) which is quite approximate to the original intended meaning.

4.2 Sexual intention

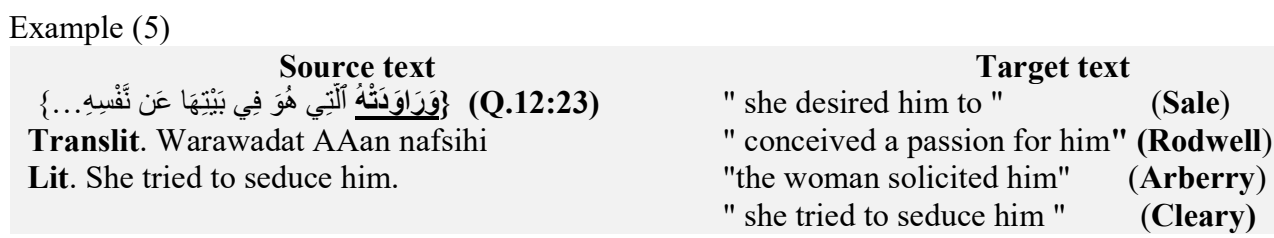

In example (5), the use of the euphemism 'rawadat-hu' (lit. tried to seduce him) does not only entail a female's desire for having sex with a male but also her very powerful repetitive insistence on fulfilling this desire (Qutb,2003, p.1980; see Al-Qurtubi 2006). The extract in above example narrates part of prophet Yusuf's (Joseph) story which reads that while he lived in the house of Al-Azeez, i.e. the minister of Egypt, and because Yusuf is extremely handsome, the minister's wife was deeply bewitched by him and attempted to seduce him (Az-Zamakhshari, v.12.p.509, At-Tabari, vol.16, p.24; Qutb, 2003, p.1980).

In line with this, the translations examined are at variance in rendering the euphemistic expression 'rawadat-hu' in example (5). It is rendered into 'desired him' by Sale and this translation is functional because the euphemistic expression used, i.e. desired him, indicates a strong wish to have sex with someone (Holder, 2008, p.150), but still the repetition of the act embedded in the ST is not yet adequately communicated. In addition, 'rawadat-hu' is translated into "[she] was conceived a passion for him", by Rodwell, which semantically partially expresses the meaning intended but the richness of the ST is not reflected since the word 'passion' refers to a strong desire for someone or something, but it does not convey the meaning of seduction and the relevant connotations of the source message. In this context, the source CBEE is rendered into 'solicited him' by Arberry and this expression refers to the offer of "sexual services for money..." (Holder, 2008, p.355). Accordingly, this meaning does not fit the ST, which implies both sexual act and seduction at the same time, and the minister's wife had a real strong desire for Yusuf but she did not offer sex for money. Besides, the ST is translated into 'tried to seduce him' which seems to partially express the original since 'seduce' is more related to male's seduction of women because it literally means "to persuade a woman to copulate with you extramarital" (Holder, 2008, p.336). In addition, the woman's repetitive attempts embedded in the ST are not conveyed by the use of 'seduce' in English. It is rather a translation of the intended meaning without attempting to find the euphemistic equivalence. The following translation seems to better fit the ST intended message: "She sought to seduce him..."(Hilali and Khan, 1977, p.306)

This expression, as Abdul Fattah (2014) asserts, "renders the exact meaning of the term rāwādathu and the euphemistic expression as rich as the original in a parenthetical sentence" (p.18).

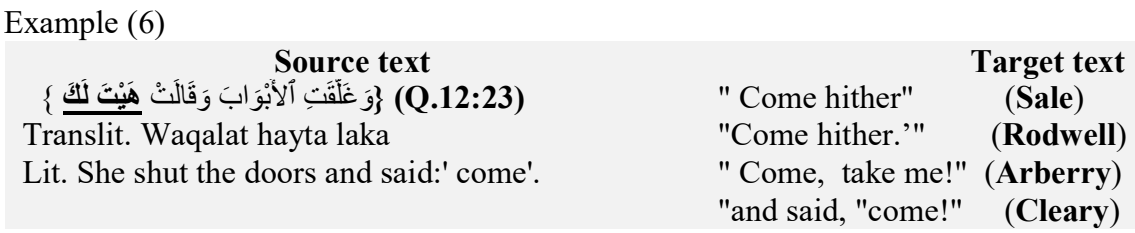

This verse is part of the previous one where they are contextually co-presented and the expression 'hayta laka', cotextually, reveals the minister's wife's non-stop attempts to seduce Yusuf. More specifically, the use of rāwädathu in the previous part in combination with her obvious action of shutting all the doors, in this part, and her explicit invitation to Yusuf via uttering 'hayta laka' (come on) are all co-texts that the woman's intention is to have sex with him (AzZamakhshari, 1998, vol.12, p.510; Qutb, 2003, p.1981).

In the light of the above exegetical account, the expression 'hayta laka' is rendered into 'come hither' by Sale and Rodwell and this euphemistic expression entails an invitation to sexual approach especially when the female is involved in the act of seduction (Holder, 2008, p.128). What is lacking in the previous translation is that the woman's repetitive insistence is not communicated in the TT. In contrast, 'hayta laka' is transferred into 'come', by Arberry and Cleary, which seems irrelevant to the context in question because the verb 'come', when used alone as euphemism, refers specifically to the act of achieving sexual orgasm and it has nothing to do with seduction (Rawson,1981, p.53; Holder, 
2008, p.129). Therefore, this translation is not only far from the intended meaning but it also never conveys the act of seduction and the repetitive nature of that act as embedded in the ST. Cleary's use of an exclamation mark may reflect the woman's shameless lustful desire for Yusuf but still the translation is non-equivalent to the ST. Obviously, the ST should be better rendered into:

-She locked the doors and said: "Come on!" (Bell, 1937, p.219).

This translation seems quite functional since the English euphemism 'come on' is "an invitation to another to make a sexual approach and 'to come on' means that a female is so signaling a male"(Holder, 2008, p.129).

Example (7)

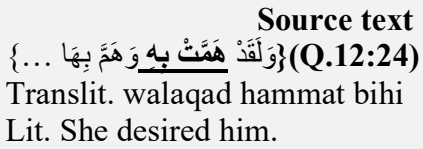

\begin{tabular}{|c|c|}
\hline \multirow{2}{*}{\multicolumn{2}{|c|}{$\begin{array}{l}\text { Target text } \\
\text { "she resolved to enjoy him" (Sale) }\end{array}$}} \\
\hline & \\
\hline 'But she longed for him' & (Rodwell) \\
\hline lesired him;!" & (Arberry) \\
\hline et she did desire him & (Clear \\
\hline
\end{tabular}

In example (7), the term 'hammat bihi' is a "metonymy that is a euphemism for an extramarital sexual relation motivated by a sense of propriety to avoid mentioning an embarrassing term, namely illegal sexual intercourse" (Abdul Fattah, 2014, p. 27). This verse forms a continuation of Prophet Yusuf's story with the minister's wife, as detailed previously, and in this example, she started to come closer to him trying to seduce him via explicitly showing her sexual desire to him (Ar-Razi, 1981, Qutb, 2003).

In this example, the word 'hammat bihi' is rendered into 'to enjoy him' by Sale and this euphemistic expression refers to male's desire to copulate with a female (Holder, 2008, p.167). This translation conveys both the intended meaning and the function since the translator's use of "she resolved within herself" 'before the verb 'enjoy' may reflect the repetition of action implied in the ST. The ST expression is translated into"she longed for him", by Rodwell, which does not entail any sexual connotations (Rawson, 1981; Holder, 2008), and it is therefore not the right counterpart for the ST. Conversely, the expression 'she desired/did desire him' is employed by Arberry and Cleary respectively and this rendition communicatively encodes the meaning of 'hammat bihi'. This translation seems the more approximate rendering of the ST for it implies a strong desire to have sex (Holder, 2008, p.150), however, the ST embedded connotations, as stated above, have not yet decoded perfectly. The following translation may be more accurate and communicative:

-'And (with passion) did she desire him, and he would have desired her' ( Ali, 1998, p.281)

Ali's translation is more functional due to the translator's addition of 'with passion' to differentiate between her desire and his since they are totally different (Abdul Fattah, 2014, p. 27).

Example (8)

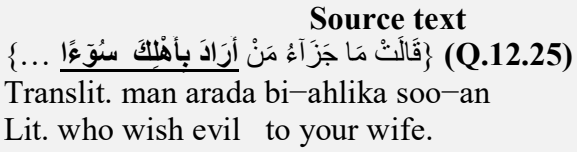

Lit. who wish evil to your wife.

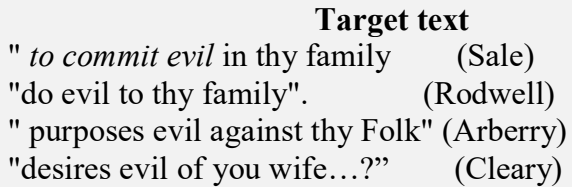

In example (8), the expression 'arada bi-ahlika soo-an' is a euphemism for illegal sexual intercourse, i.e. adultery, which is highly euphemized in the Qur'an due to the very negative connotation it has (Ar-Razi, 1981, Qutb, 2003). This verse is also part of prophet Yusuf's story with the minister's wife but in this context she and Yusuf raced each other to the door for the latter attempted to escape. Meanwhile, they both were facing her husband at the door where she found no excuse but to accuse Yusuf of attempting to commit adultery with her ( Az-Zamakhshari, 1998 vol.12, p.512; Qutb, 2003, p.1982).

In line with this, the expression 'arada bi-ahlika soo-an' is rendered into 'evil' by all the translators selected but they vary in the verbs used with 'evil'. As for Sale, 'seketh to commite evil' is used as a counterpart to ST, while the original is rendered into 'would do evil' by Rodwell. In Arberry's translation, the original text is transferred into 'purposes evil' whereas it is rendered into 'desired evil' in Cleary's. However, all the translators seem unable to find the functional or even the approximate rendition because the use of the word 'evil' with all the verbs mentioned above does not provide any meaning related to the original intention, i.e. illegal sexual act. Also, all the translations cited seem much more misleading to the target reader since 'evil' is a very much literal and general term which never expresses or even hints at any sexual connotations (Rawson, 1981; Holder, 2008). The following translation is more functional:

- She said, 'What... should be the reward of someone who tried to dishonour your wife?' (Abdel Haleem, 2005, p.146)

The use of this euphemism, i.e. 'dishonor', expresses exactly the intended meaning in the above example since to dishonor a female is to copulate with her outside marriage (Holder, 2008, p.154).

4.3 Bodily parts

Example (9)

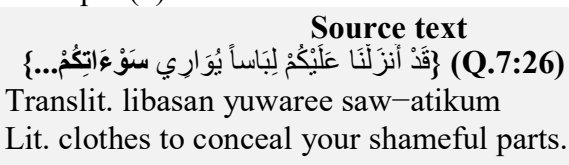

Target text

$\begin{array}{lc}\text { " cover your shame" } & \text { (Sale) } \\ \text { " hide your nakedness" } & \text { (Rodwell) } \\ \text { " cover your shameful parts" } & \text { (Arberry) } \\ \text { " to cover your private parts" } & \text { (Cleary) }\end{array}$


In the Qur'an, the word 'sawaa' is used as euphemism to hint at man's private parts to avoid direct reference to them since they are distasteful to mention explicitly (Al-Tabari,2000, vol.12, p.361; Al-Omoosh, 2010, p.81). This extract is contextually concerned with reminding humans of God's signs. This verse is about the sign of sending down garments to hide man's sawa'a' (lit. shameful part) (Az-Zamakhshari, 1998, vol.8, p. 360; Qutb, 2003, p.1277).

In the above translations, 'sawaa' is transferred into 'shame' by Sale but this translation is nonequivalent to the ST due to its irrelevance to any sexual parts. Rather, the word 'shame' describes "extramarital copulation by a woman"(Holder, 2008 , p.341), and this translation is a real socio-pragmatic failure because the translators seem unaware of both the intended meaning and the inappropriateness of using the word in question, i.e. shame. In example (9), the source CBEE is rendered into 'nakedness', by Rodwell, which is quite a general term and never conveys any sexual implications. It rather refers to nakedness of the whole human body (Oxford Advanced Learner's Dictionary). In contrast, 'shameful parts' is used, as equivalent to the ST, by Arberry and this rendition is unsuitable to the target reader since English never uses 'shamfeul' with human privates but it uses 'intimate/private' parts instead (Holder, 2008, p.229). Arguably, the word 'sawaa' seems to be decoded functionally into English 'private parts' by Cleary and this translation conveys both the meaning and function of the ST.

Example (10)

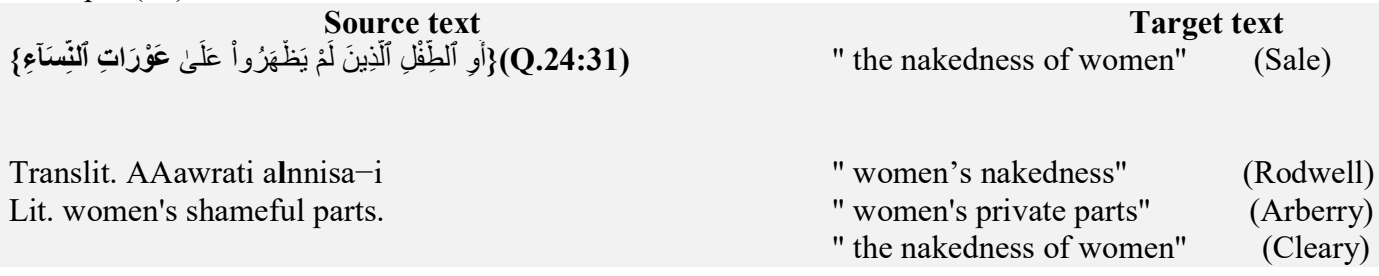

In the above example, the word 'aawra', being synonym to 'sawaa' discussed in the previous examples (9), is used euphemistically to entail human private parts (Al-Tabari, 2000 vol.19, p.163; al-Omoosh, 2010, p.82). In this example, the Qur'anic discourse regulates the believing women's relations with believing males and the former are accordingly not allowed to expose some of their body parts that may cause temptation. In contrast, some persons are excepted from this prohibition, namely their husbands, sons, their sister's sons...etc. More specifically, among the excepted ones are "children who are not yet aware of women's private parts (Ar-Razi, 1981, vol.23, p.203; Az-Zamakhshari, 1998, vol.18, p.727). As for as translation is concerned, 'aawra' is rendered into 'nakedness' by Sale, Rodwell, and Cleary where 'nakedness', as discussed previously (example 9), reflects no sexual connotations but it rather refers to the exposure of the whole body and this is not the intended meaning in this context. In contrast, the ST expression is translated into' private parts' by Arberry and this translation seems more functional and more convincing because it conveys the intended meaning, i.e. 'sexual private parts' (Rawson, 1981; Holder, 2008).

\section{Conclusion}

In this study, the discussion and analysis reveal that viewing the translation equivalence in the light of the new translation theory discredits the claims that lead to the emergence of the notion of untranslatability. In other words, translation equivalence is re-established as relative, approximate and necessary identity and untranslatability is based on full equivalence which doesn't exist. More specifically, Catford's notion of untranslatability has been emerged due to the narrow view the linguistic approach to translation, he adopts, provided to equivalence in such a rigid and static way. Consequently, Catford seems to be unaware of the dynamic nature of language and culture and that nothing, accordingly, is untranslatable. Therefore, researchers describe untranslatability as a false theorization and even a myth that is divorced from reality. Also, globalization and communication technology plays a major role in bridging the gaps between cultures that are ultimately different. As argued in this paper, FE seems the best strategy in translating CBEEs in the Qur'an, for it is mainly concerned with the rendition of both the meaning and the function of the original in the TT. Based on the analysis of the examples above, translatability is translator-dependent since qualified translators can creatively find an equivalence of some kind even to the most translation-resistant texts.

\section{References}

Abdel Haleem, M. A. (2005). The Qur'an. Oxford: OUP Oxford.

Abdul Fattah, M. (2014). Translating Euphemism of Sexual Taboo in the Quran. Retrieved from https://www.academia.edu/8312002/Translating_Euphemisms_of_Sexual_Taboos_in_the_Qur_an.

Abu-Mahfouz, A. (2011). Some issues in Translating Nouns in Abdullah Yusuf Ali's Translation of the Meanings of the Holy Quran. Jordan Journal of Modern Languages and Literature, 3(1), 65-83.

Al-Omoosh, A. (2011). Euphemism in the Holy Qura'an. (MA Thesis ), Al-albayet Univesity, Jordan.

AL-Qurtubi, A. A. M. (2006). al-Jami' Ii Ahkam al-Qur'an.Beirut: Dar al-Risalah.

Al-Tabari, M. b. J. (2000). Jami al-Bayan Fi Taweel al-Qur'an: Al-Risala foundation.

Ali, A. Y. (1998). The Holy Qur'an. Kuala Lumpur: Saba Isalmic Media.

Ar-Razi, M. F. (1981), al-Tafsiral-kabir Beirut: Dar al-Fikr.

Arberry, A. J. (1955). The Koran Interpreted. New York: Macmillan.

Az-Zamakhshari, A. (1998). al-Kashshaf. . Riyadh: al-Obeikan. 
Badawi, M. F. (2008). Investigating EFL Prospective Teachers' Ability to Translate Culture-Bound Expressions. Online Submission.

Bahameed, A. (2008). Hindrances in Arabic-English intercultural translation. Translation Journal, 12(1), 1-16.

Bassnett, S. (2002). Translation Studies (third ed.). London and New York: Routledge. .

Belanos, S. C. (2002). Equivalence Revisited: A Key Concept in Modern Translation Theory. Forma Y Function(15), 60-88.

Bell, R. (1937). The Qur'an Translated, with a Critical Re-arrangement of the Surahs. New York: Charles Scribner's Sons.

Bell, R. T. (1991). Translation and translating (Vol. 56): London: Longman.

Catford, J. C. (1965). A linguistic theory of translation (Vol. 31): Oxford University Press London.

Cleary, T. (2004). The Qur'an. USA: Starlatch Press.

Cluz, M. (2001). Aspects of Untranslatability on the Basis of Two Plish translations of Winnie-the-Pooh by A.A.Milne. Krakow: Jagiellonian University.

Cui, J. (2012). Untranslatability and the Method of Compensation. Theory and Practice in Language Studies, 2(4), 826830.

Cymbalista, P. (2003). Untranslatability as Culture-Specific Phenomenon. Retrieved from https://www.ur.edu.pl/file/1251/sar_v2_02.pdf

Dawood, N. J. (1978). The Koran. Harmondsworth, Middlesex: Penguin Books.

De Pedro, R. (1999). The Translatability of Texts: A Historical Overview. Meta: Journal des traducteursMeta:/Translators' Journal, 44(4), 546-559.

Faisal, T. A. (2014). Explication: A Problem-Solving for Translating Arabic Religious Non-Equivalent Items Into English. Adab al-faraheedi Jouranal(19), 333-356.

Harvey, M. (2002). What is So Special About Legal Translation? . Meta.

Hilali, M. a. K., M.M. (1977). Interpretation of the Meanings of the Noble Qur'an in the English Language. Riyadh: Darussalam.

Holder, R. W. (2008). A Dictionary of Euphimism:How Not To Say What You Mean. Oxford New York: Oxford University Press.

House, J. (1997). Translation Quality Assessment: A Model Revisited. . Tübingen: Narr.

House, J. (2009). Translation (first ed.). Oxford New York: Oxford University Press.

Hulusi, A. (2013). Decoding the Qur'an: A Unique Sufi Interpretation.

John, M. (2011). Untranslatability is a Myth. Dyke, 5(1), 1-20.

Kitamura, K. (2009). Cultural untranslatability. Translation Journal, 13(3).

Leonardi, V. (2000). Equivalence in Translation: Between Myth and Reality. Translation Journal, 4(4).

Motamadi, A. (2008). A Glossary of Concepts and Terms in Translation Studies. Tehran: Rahnama Press.

Newmark, P. (1988). Approaches to translation. London: Prentice Hall.

Nida, E. A. (1964). Towards a Science of Translating Translating. Leiden, Holland: E.J. Brill.

Nida, E. A. (1993). Language, culture, and translating. Shanghai: Foreign Language Education Press.

Nida, E. A. (2001). Language and Culutre: Contexts in Translating: John Binjahmins Publishing Co.

Panou, D. (2013). Equivalence inTranslationTheories: A Critical Evaluation. Theory and Practice in Language Studies, 3(1), 1-6.

Qutb, S. ( 2003.). FI Zilal al-Qur'an. Cairo: : Dar al-Shuroq.

Ranua, M. (2009). Connotations in Kenneth Grahame's the Wind in the Willows and Its Finnish Translation. (Apro Gradua Thesis), Unversity of Jyaskyla.

Rawson, H. (1981). Dictionary of Euphemisms \& Other Doubletalk. . New York :: Crown Publishers, Inc.

Rodwell, J. (1909). The Koran Translated from Arabic. London: : J.M. Dent\& Sons Ltd.

Sale, G. (1927). The Koran. Translated into English from the Original Arabic. London: Fredrick Warne and Co. Ltd.

Samuel, M., \& Samuel, K. (2007). Critical Approaches to The Notion of Translatability and Untranslatability of Texts in Translation Studies. Pak. J. Soc. Sci, 4(3), 375-379.

Shiflett, M. M. (n.d.). Functional Equivalence and its Role in Legal Translation: English Matters III. Retrieved from https://www.pulib.sk/web/kniznica/elpub/dokument/.../mullerova.pdf .

Snell-Hornby, M. (1988). Translation Studies : An Integrated Approach. Philadelphia: John Benjamin's Publishing.

Weston, M. (1991). An English Reader's Guide to the French Legal System. New York, and Oxford: Berg.

Wilss, W. (1992). The Science of Translation; Problems and Methods. Gunter NarrVerlag: Tubingen.

Yinhua, X. (2011). Equivalence in translation: Features and necessity. International Journal of Humanities and Social Science, 1(10), 169-171.

Zhang, Q. (2010). Application of Functional Equivalence Theory in English Translation of Chinese Idioms. Journal of Language Teaching and Research, 1(6), 880-888. 